\title{
CÃO ANALISTA SOCIAL: A IRONIA DE UM TEXTO QUEIROSIANO QUE SUBVERTE AS RELAÇÕES ENTRE SERES HUMANOS E ANIMAIS
}

Rodrigo do Prado Bittencourt ${ }^{1}$

RESUMO: Este artigo analisa um texto de Eça de Queirós publicado na imprensa portuguesa, em 1884: "A Inglaterra e a França julgadas por um inglês". Neste conto, um cão inglês escreve para sua amiga - uma gata - a respeito da França. Há ironia e intensa crítica social na carta canina. O conto analisa questões como a hipocrisia, a superficialidade, a arrogância, a imparcialidade e a relação entre os humanos e os animais. Há nele uma espécie de humanização do cão e desumanização do povo inglês, descrito como repleto de vícios, tolo e infeliz.

PALAVRAS-CHAVE: Eça de Queirós; Alteridade; Fantástico; Inglaterra; Século XIX.

\section{SOCIAL ANALYST DOG: THE IRONY OF A QUEIROSIAN TEXT THAT SUBVERTS THE RELATIONS BETWEEN HUMAN BEINGS AND ANIMALS}

ABSTRACT: This article analyzes a text of Eça de Queirós published in the Portuguese press, in 1884: “A Inglaterra e a França julgadas por um inglês". In this tale, an English dog writes to his friend - a female cat - about France. There is irony and an intense social criticism in the canine letter. The tale analyses issues such as hypocrisy, superficiality, arrogance, impartiality and the relation between human beings and animals. There is, in this story, a kind of humanization of the $\operatorname{dog}$ and dehumanization of the English people, described as full of vices, foolish and unhappy.

KEYWORDS: Eça de Queirós; Alterity; Fantastic; England; 19th Century.

Eça de Queirós foi um escritor muito prolífico, ficando mais conhecido por seus romances, mas tendo produzido diversos textos para a imprensa, contos, artigos de análise de política internacional e hagiografias. Quanto à atividade jornalística do autor, percebe-se que ela tem sido cada vez mais difundida pelo grande público e, sobretudo, pelo meio acadêmico, graças ao trabalho crítico e investigativo de pesquisadores especializados no estudo do escritor português. Dentre estes estudiosos, destaca-se Elza Miné, cujas obras sobre os textos queirosianos publicados na imprensa tornaram-se referência (MINÉ, 1986; 2000). Além disso, ela - Miné - foi uma das pessoas que contribuiu para um amplo trabalho de pesquisa e produção editorial, que tem resgatado o texto queirosiano em sua forma original: trata-se do projeto coordenado por Carlos Reis, professor catedrático da

\footnotetext{
${ }^{1}$ Doutor egresso pela Universidade de Coimbra.

${ }^{2}$ Professora mestra no Instituto Federal de Minas Gerais (IFMG).
} 


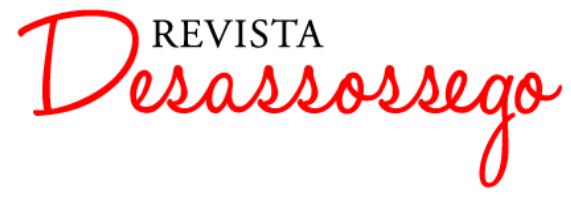

DESASSOSSEGO 19 | JUN/2018 | ISSN 2175-3180

DOI: http://dx.doi.org/10.11606/issn.2175-3180.v10i19p26-38

Universidade de Coimbra, que desde 1992 está a realizar a edição crítica de toda a obra de Eça de Queirós.

Apenas por meio de um rigoroso trabalho como este se pode ler as diversas obras deste célebre autor, passando ao largo dos inúmeros erros, intrusões e omissões que infelizmente atingiram os textos deste escritor ao longo dos anos; como é comum acontecer com todas as obras que passaram por diversas edições (nem sempre bem cuidadas), ao longo de mais de um século.

Infelizmente, o trabalho de publicação da edição crítica das obras de Eça de Queirós ainda não terminou e os leitores comuns e mesmo os pesquisadores são obrigados a recorrer ainda às diversas edições portuguesas e brasileiras das obras de Eça de Queirós. É o caso do texto que aqui se analisa, lançado na coletânea Notas Contemporâneas, editada por Luís de Magalhães e publicada em 1909.

O conto “A Inglaterra e a França julgadas por um inglês" foi publicado n'A Ilustração, em 1884. Deve-se recordar que, a esta altura, Eça já era o conhecido autor de O crime dopadre Amaro (1875), O primo Basílio (1878), O Mandarim (1880) e de diversos contos e crônicas. Ainda assim, não foi n'A Ilustração que Eça publicou a maior parte de seus textos destinados a jornais. Ao contrário, chama a atenção o fato de que ele pouco publicará neste veículo durante toda a sua vida. Essa colaboração é uma exceção; como o próprio texto deve ser encarado como exceção, no interior da obra de Eça. Discutir-se-á, a seguir, o caráter excepcional deste conto, de modo a situá-lo na produção artística do escritor

"A Inglaterra e a França julgadas por um inglês" apresenta-se como uma obra de caráter duplo: fantasiosa e ao mesmo tempo de forte apego às realidades históricas e sociais. Trata-se de um texto que reproduz uma carta escrita pelo cachorro do cronista à gata do mesmo dono, que ficara em Inglaterra enquanto cão e dono viajavam pela França. $\mathrm{Na}$ carta, o cão conta suas impressões sobre a França e reflete também sobre a Inglaterra. Antes disso, porém, o cronista analisa a história da raça pug, ou carlin, ligando-a à aristocracia e à realeza francesas e à sua emigração para a Inglaterra, na época da revolução (1789-1799).

O texto é cheio de ironia para com a Inglaterra, que estaria repleta de súditos submissos e alienados; além de homens iguais, com ideias e casas iguais. Durante todo o texto, o cão sempre cita um inglês, que está constantemente a escrever cartas para o Times, nas quais formula sentenças sempre óbvias, vazias e idiotas. 
Critica-se também o falso moralismo inglês e seu orgulho sem medidas. Orgulho que acaba por convencer os outros povos, e o próprio inglês, de sua superioridade. O pug chega a dizer que a maior qualidade dos ingleses é sua habilidade em fazer propaganda (QUEIRÓS, 1913, p. 109). O conto critica ainda a desigualdade social na Inglaterra, dizendo que ela entra em contradição com a civilização e a liberdade (QUEIRÓS, 1913, p. 110). Outro tema ainda candente, na atualidade, e de intensa repercussão filosófica.

Os ingleses se caracterizariam por generalizações absurdas semelhantes às do cão (QUEIRÓS, 1913, p. 112-3). Assim, a inteligência inglesa é comparada com a de um cão e os males sociais deste país são duramente criticados. Este aspecto remete o leitor familiarizado com o romance inglês do século XIX a obras de Dickens, sobretudo The Pickwick Papers (1837). Afinal, a superficialidade de Mr. Samuel Pickwick lembra as generalizações do "Amigo da Imparcialidade", que é como se denomina o correspondente do Times citado pelo pug. Além disso, também a obra de Dickens está repleta de alusões e denúncias dos males sociais ingleses, sobretudo no que se refere às péssimas condições de vida dos encarcerados.

Um ponto importante a se ressaltar, no que se refere ao texto "A Inglaterra e a França julgadas por um inglês", é o tema da Inglaterra e dos ingleses, tantas vezes trabalhado por Eça. Com efeito, ele já aparece em alguns dos textos de imprensa que depois foram reunidos no livro Prosas Bárbaras (textos originalmente publicados nos anos de 1866 e 1867); segue na irreverente iniciativa literária que resultou n'O Mistério da Estrada de Sintra (1870); continua em alguns textos d'As Farpas escritos por Eça de Queirós (1871-1872); ressurge na seção em que o escritor produz sua colaboração para o periódico $A$ Actualidade (com os nomes de Crônicas de Londres e de Cartas da Inglaterra) entre 1877 e 1878; aparece ainda numa colaboração enviada para a Gazeta de Notícias com o nome de Um artigo do $<<$ Times $>>$ sobre o Brasil (1880), em que critica fortemente a imprensa inglesa; e finalmente ressurge no texto aqui analisado, antes de aparecer no livro queirosiano em que mais marcantemente se respira ares ingleses: Os Maias (1888).

Neste último romance, temos não apenas a estadia de Afonso em Inglaterra, devido à perseguição miguelista, e sua consequente admiração pela aristocracia Tory; bem como a educação de Carlos da Maia segundo o modelo inglês e com um preceptor desta nacionalidade (evidentemente estereotipado); a dúvida de Sousa Neto sobre a existência ou não de literatura em Inglaterra e, por fim, Miss Sarah, a marcante governante inglesa de Maria 
Eduarda. Há que se recordar que aparece esta mesma personagem, com algumas modificações, no romance de Eça sobre incesto que ficou inédito, como um rascunho não desenvolvido, e que muito depois de sua morte foi lançado com um dos títulos que o escritor pensava dar à obra: A tragédia da Rua das Flores (1980). O que se pode notar em todas estas referências à Inglaterra e a ingleses e inglesas? É difícil traçar uma síntese e só a tentativa de o fazer já demandaria um livro, pois complexa é a relação entre Eça e a Inglaterra, país em que morou, como cônsul de Portugal, primeiramente em Newcastle Upon Tyne e depois em Bristol. Ainda assim, pode-se perceber duas linhas mestras a conduzir a atitude do escritor diante deste país: a admiração e a ironia crítica. Assim, é possível afirmar que em seus textos há a presença de atitudes de admiração pelo poderio inglês, por sua literatura, suas maneiras e educação, mas também a crítica irônica por sua hipocrisia, sua ganância, sua cruel desigualdade social, sua arrogância diante dos países mais fracos, sua atitude imperialista e sua superficialidade.

Após esta breve análise da ocorrência de referências à Inglaterra e seu povo na obra de Eça, é possível agora situar o texto aqui estudado em meio à obra queirosiana, como um todo. Este texto deve ser visto como apenas indiretamente conectado com outros da obra de José Maria Eça de Queirós, por seu caráter irônico e de crítica social. O seu caráter fantástico, entretanto, o faz destoar de maioria dos textos do autor, com exceção de $O$ Mandarim, que também se aventura pelos caminhos da fantasia e da imaginação.

O Mandarim representa um ponto de viragem na obra de Eça de Queirós. Desde as Conferências do Casino de Lisboa e do início de sua colaboração n’As Farpas, escritas juntamente com Ramalho Ortigão, Eça não se dedicava a textos fantásticos. Introdutor do Realismo em Portugal, ele abandonou os temas fantásticos de sua literatura pregressa a partir do contato com Proudhon, advindo por meio da influência de Antero de Quental. Ao menos, é o que se pode depreender do testemunho do próprio Eça de Queirós, em texto que homenageia o amigo, que cometera o suicídio. Assim, a partir de 1871 (ano em que ocorrem as Conferências, logo proibidas pelo governo português, e se inicia a publicação d'As Farpas), os textos do jovem escritor dedicar-se-ão a tratar, ainda que com bom humor e mordaz ironia, de realidades empíricas, individuais e coletivas, sem se afastar daquilo que se denomina e se convenciona como "real".

O Mandarim apresenta uma versão moderna do pacto diabólico, introduzindo na discussão a respeito do tema da riqueza, da bajulação e da culpa, um elemento fantástico. 
Assim, Eça de Queirós volta a assumir uma liberdade criativa mais ampla, que fora momentaneamente abandonada, em prol dos ideais proudhonianos e do Realismo. É esta liberdade maior que lhe permitirá adotar um narrador pouco fidedigno em sua obra-prima, Os Maias, obra em que o narrador, logo de início, informa ao leitor que os membros da família Maia são dois (Carlos e seu avô, Afonso) e no fim da narrativa o leitor se depara com mais uma pessoa pertencente à família em questão: Maria Eduarda, a irmã de Carlos e sua amante, quando ainda inconsciente do grau de parentesco existente entre os dois (FREELAND, 1989). Esta "mentira" do narrador faz-se necessária para preservar a surpresa do desenlace final, permitindo, assim, um enredo dramático, como traços de tragédia grega, como grande parte da crítica queirosiana já notou.

Esta transformação da narrativa queirosiana se mostra evidente em "A Inglaterra e a França julgadas por um inglês". Para a crítica social contida no texto em questão, Eça quis usar de um ser aparentemente ingênuo, um cão, pretensamente incapaz de entender de modo maduro e seguro o gênero humano. O que se percebe, porém, é que a realidade não é exatamente esta e o cão acaba por traçar reflexões algo profundas a respeito do que vê em seu país.

O cão, que atende pelo nome de "D. José", apresenta um comportamento tipicamente inglês, enquanto pug que nasceu e foi criado em tal ambiente. Percebe-se que o narrador se utiliza dele para promover a ironia com relação aos costumes ingleses, à conduta dura e mesmo pomposa associada aos britânicos. Por meio da narrativa epistolar realizada por D. José, é possível perceber que o cão se torna extremamente seduzido pela cultura francesa. Não se pode olvidar que a carta possui a intenção de tocar seu leitor, para que ele seja impulsionado a retornar a escrita. O destinatário da carta é a gata Pussy, que divide a moradia com D. José e seu dono. Ao longo da história e dos mitos, os gatos foram associados a uma postura hedonista, sonolenta, sensual e até preguiçosa. A maneira de lidar com as questões francesas e a escolha do vocabulário provavelmente tinha por intenção, além da pompa habitual britânica, de encantar a felina. O próprio texto evidencia a personificação britânica no cão e a suavidade da gata:

«D. José» é um cão inglês, gordo, sisudo, conservador, que agora pela primeira vez saiu de Inglaterra comigo, e veio descansar de um rude Inverno saxónio nestes ares suaves, tépidos, quase latinos, do país de Anjou. «Pussy» é uma gata inglesa, cor de manteiga, que ficou em Inglaterra, caseiramente, a dormir ao canto do fogão. 
«D. José» pertence a essa raça de cães ilustre e histórica que os Ingleses chamam pug e os Franceses carlin. Italiano de origem, introduzido em França pelo cardeal Mazarino, o carlin tornou-se, desde o século XVII, o cão favorito da Monarquia, como o galgo tinha sido o cão fiel do Feudalismo. [...] O carlin pesado, obeso. Pacato, cerimonioso, era realmente o cão que convinha agora à França centralizada e unificada sob a autoridade real. Por isso ele é essencialmente o cão de Luís XIV e de Versailles, - tão característico do Grande Século como as cabeleiras de cachos, a tragédia clássica e a aparatosa simetria dos jardins de Le Nôtre. (QUEIRÓS, 1913, p. 99)

Interessante a analogia realizada entre a perífrase do Rei Luís XIV como o estado na figura de sua majestade e o aumento de cães da raça pug/carlin na corte francesa. Apesar da origem italiana, como o conto nos informa, tal raça vigorou na França e, mais tarde, como presente e mesmo estilo de vida, chegou à Inglaterra. Neste ponto, podemos perceber no texto uma tentativa de historicizar a relação de cães com humanos, demonstrando como as raças foram associadas a qualidades e mesmo a determinados status sociais.

Ao analisar as diferenças entre os dois países, D. José discorre sobre a superioridade do clima francês, que chega a desanuviar-lhe as ideias ["pensar torna-se para mim um prazer delicado" (QUEIRÓS, 1913, p. 100)]. "Nada facilita mais uma civilização que um bom clima", diria o inglês gordo que o cão passou a observar no hotel, correspondente de política e moral do Times (um dos jornais mais conceituados à época) com a assinatura de Um amigo da Imparcialidade, sobre o qual nos debruçaremos mais adiante.

Outra questão analisada por D. José diz respeito à padronização de raças de cães, figurino, comportamento, arquitetura, mobília e até opiniões inglesas. "O grande horror da nossa pátria é a mesmice” (QUEIRÓS, 1913, p. 101). O comportamento francês, segundo ele, é jovial, irreverente, diverso e excitante, citando a mistura de raças de cães, a leveza das cadelas, a espontaneidade das mulheres.

Ao tocar na moralidade na Inglaterra, D. José acaba por vociferar sua indignação como animal que se sente inferiorizado pelos humanos:

Nós em Inglaterra afirmamos, com a Bíblia apertada contra o coração, e a garrafa de gin escondida debaixo da mesa, que a moralidade dos nossos costumes é superior à de todas as nações do Universo. Tu sabes, Pussy, como esta pudica afectação nos parece divertida, a nós cães e gatos, testemunhas permanentes da vida Intima, diante de quem os seres racionais, no seu imbecil orgulho e supondo que somos mudos, não se dão ao incómodo de ter recato... (QUEIRÓS, 1913, p. 102). 


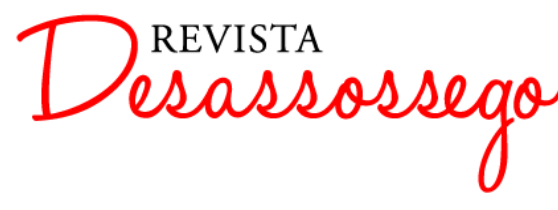

DESASSOSSEGO 19 | JUN/2018 | ISSN 2175-3180

DOI: http://dx.doi.org/10.11606/issn.2175-3180.v10i19p26-38

O biólogo Jean-Didier Vincent, no livro em parceria com o filósofo Luc Ferry, intitulado O que é o ser humano? (2011) vê a linguagem humana como uma habilidade desenvolvida através do instinto e resultado da hereditariedade. Ele questiona e responde:

\begin{abstract}
Se o homem é um animal, será que a linguagem seria um instinto que pertence só a ele? Nesse caso, será que ele é o produto de uma ruptura catastrófica no seio do reino animal, ou mais "naturalmente" o resultado da seleção natural e de uma evolução gradual, assim como a bipedia nos homínidas ou o voo das aves num outro ramo da árvore filogenética? $\mathrm{O}$ instinto é uma capacidade inata de um animal a adquirir um comportamento típico da espécie em condições apropriadas de meio e particularmente em contato com parentes e congêneres. Verdadeiramente falando o homem aprende a falar, assim como o pássaro aprende a voar, nada mais. Este saber é deposto por seus genes em seu cérebro, e é o congênere que lhe revela este tesouro (2011, p. 127).
\end{abstract}

Ainda que mais articulada e complexa, a linguagem do homem é resultado da necessidade e interação com o meio e com seus pares. Há uma linguagem e uma técnica elaborada pelas espécies animais. Esse pensamento desfaz, de certa maneira, a superioridade do homem frente a outros seres vivos, aproximando as fronteiras e apagando as diferenças elencadas ao longo dos séculos.

Todavia, o uso da técnica, ao servir, ao longo da história, enquanto instrumento de controle e poder por parte dos homens, fez com que a diferença entre humano e não humano, justificada pela cultura, fosse apagada de uma forma negativa. É a teoria que Foucault começou a desenvolver através de seus estudos sobre a loucura e a sexualidade, e que Giorgio Agamben aprofundou em suas pesquisas, que podemos chamar de Biopolitica. Quando as forças políticas descobrem o valor desse instrumento chamado corpo, a definição de vida e o limiar entre humano e não humano entram numa espécie de crise. O centro das investigações da atual filosofia recai não apenas sobre o corpo, mas de um modo mais abrangente, sobre a vida, sobre os seres viventes e suas relações entre si, na sociedade e na política.

As pesquisas do etólogo Dominique Lestel tentam provar que os animais também devem ser vistos como seres portadores de uma história e de uma cultura. Em As Origens Animais da Cultura (2002), o autor reúne inúmeros dados, envolvendo atitudes de animais que se assemelham às humanas, para provar o seu ponto de vista. Uma das passagens do livro relata o caso de Mozu, um macaco fêmea do Japão, que não tem pés nem mãos, e que é auxiliado, com solicitude, pelos outros macacos da colônia. Outro caso relatado é o do 
nascimento do filhote da chipanzé Moi, motivo de cenas extraordinárias de alegria entre os outros membros do grupo, que foram registradas por pesquisadores.

O intuito de Lestel, diante dessas semelhanças culturais entre as espécies, é o de demonstrar que, apesar das tantas fronteiras que antes de nos separar dos animais, nos unem a eles, o homem continua ignorando-os. São cada vez mais graves os problemas que diversas espécies vêm enfrentando, justamente por causa da suposta hierarquia humana, diante do planeta, que, ao pensar somente no progresso e conforto de sua espécie, anula e coloca as outras em situação de risco e extinção.

Conforme expõe Lestel, "recolocar plenamente o homem na animalidade não significa de modo algum reduzi-lo ao animal. O ser humano deve, porém, ser repensado de alto a baixo e a sua diferença deve ser reavaliada" (op. cit., p. 268). É nesse sentido que os estudos dedicados aos animais, seja na Antropologia, na Etologia, na Biologia ou nos Estudos Culturais caminham, tentando dar um novo sentido às relações entre homens e outras espécies, ou ao menos fazer com que elas sejam motivo de reflexão, numa sociedade que, a cada dia, perde mais o contato com a natureza. Res-significar a relação entre humano e animal não se trata apenas de uma questão estética, ética ou ecológica, mas, acima de tudo, uma tentativa de sobrevivência - dos animais, dos homens e do planeta.

O filósofo Luc Ferry ${ }^{3}$ (2011) faz uma abordagem oposta às ideias de Dominique Lestel. Para Ferry, apesar das pesquisas envolvendo inteligência em macacos demonstrarem muitas semelhanças às estratégias humanas infantis, há uma diferença crucial entre os atos de ambos: no ser humano, as ações se dão com a finalidade de "comentar o mundo e partilhar seus conhecimentos com o outro" (op. cit., p. 76). Já os macacos encontram sérias dificuldades em dotar os outros de intenções. Para ele, o que nos diferencia, em grande escala, das outras espécies é a tentativa que fazemos de compreender o outro e de distanciar-se de si mesmo a fim de se interessar por ele. Assim, ao fazermos a experiência de entender esses outros, chamados "animais", também estamos promovendo um encontro com a nossa humanidade, nesse século em que o humano e o animal estão passando por uma profunda crise, e por isso, por uma intensa transformação.

\footnotetext{
${ }^{3}$ Luc Ferry está associado à corrente filosófica conhecida como humanismo secular. Ainda que essa vertente vá de encontro ao que os autores escolhidos para essa pesquisa propõem, consideremos de grande importância o contraponto teórico, para uma discussão mais fecunda e abrangente.
} 
Quando nos voltamos para os animais, damos um passo para a chamada evolução intelectual. Dizer das relações humanas e animais não implica apenas falar em simbiose e proteção animal, mas também em relações conflituosas, de embates, de lugares distintos na representação social. O simples falar sobre o outro, pensar o outro, traz consigo problemas ideológicos. Como discutir sobre os animais, se não podemos ouvi-los, deixar que eles falem por si mesmos?

Como demonstra Dominique Lestel (op. cit.), a distinção entre o homem e o animal foi vista, ao longo do tempo, como a diferença entre Natureza e Cultura, numa polaridade que não acontece de fato. Tanto o homem como o animal evoluem na interface da natureza e da cultura. Não há como negar que o acesso à interioridade do animal é uma barreira, ainda intransponível. Porém, é importante lembrar que o acesso à interioridade de outro ser humano também é, muitas vezes, problemático. No texto de Eça de Queirós aqui estudado, por meio do cão, leitores e leitoras podem perceber o quão difícil é para os humanos viverem em harmonia e quanto suas sociedades apresentam-se repletas de conflitos, ainda que mascarados mais ou menos eficazmente.

D. José percebe uma moral britânica hipócrita, bruta, monstruosa, tanto nas instituições como família, casamento, igreja, quanto no âmbito pessoal, enquanto a francesa soa-lhe mais sensível e amável. Comenta ainda da amizade entre cães de raças superiores e inferiores, num sentimento de igualdade, algo impensável em seu país e da alta gastronomia francesa.

«Passando incidentalmente a outro formoso lado da civilização francesa, deixa-me falar-te, Pussy, da cozinha. Que cozinheiros estes filhos da Gália! E como, ao pé destesrequintes e destes molhos, nós somos ainda o silvestre bretão, coberto de peles de feras, que no fundo lôbrego da sua caverna abocanhava pedaços sangrentos de carne malassada, antes de S. Patrício ter aportado a estas ilhas com a sua cruz na mão, a contarnos as coisas tristes que se tinham passado em Jerusalém!... (QUEIRÓS, 1913, p. 106).

Depois disso, a carta é abandonada e sabemos, através do narrador e dono do cão, que D. José percebeu seu retorno para o quarto do hotel. É o dono do cão que nos dá suas impressões sobre a carta de seu mascote, lembrando-nos que D. José, como legítimo cão britânico, fez análises excessivamente genéricas, evidenciando que um ser inglês, ainda que se impressione com a cultura francesa, tem nos olhos e na observação o resquício saxão. Além disso, ironiza a própria ideia de um estereótipo inglês, quando, ao início do conto, 
menciona: "Foi então que a Inglaterra recebeu da França o carlin, como já recebera outras formas do gosto, a polidez, o corte dos casacos, correcção da prosa, a ligeireza moral, os bailados e a eloquência sacra" (QUEIRÓS, 1913, p. 99).

O narrador acrescenta outros casos de generalizações e assim chegamos ao Amigo da Imparcialidade, ápice do conto, que diz respeito à tão sonhada e utópica imparcialidade em textos e notícias. O conto aponta ainda como é comum admitirmos como próprias outras opiniões, seja porque apresentam autoridade nos argumentos, seja por tradição ou modismo, deixando tantas vezes de exercer nosso próprio posicionamento diante dos fatos. Eça já apontava tal problema, ao discorrer sobre o jornalismo no século XIX.

O Amigo da Imparcialidade se configura, no conto, como epíteto irônico para apontar o óbvio, já que as citações que D. José faz do comentarista são supérfluas e nada acrescentam:

(...) quando as cousas se parecem absolutamente umas com as outras, começa a deixar de haver variedade (QUEIRÓS, 1913, p. 101)

As cousas que estão à vista, consideradas em relação às cousas que estão ocultas têm tanto para o indivíduo, como para a sociedade, a vantagem de se poderem ver! (QUEIRÓS, 1913, p. 102)

nunca se pode afirmar com certeza que uma proposição é falsa enquanto se não sabe com evidência que ela é contrária à verdade. (QUEIRÓS, 1913, p. 103)

(...) é melhor que o homem não se abaixe porque tem então, segundo as leis da Natureza, uma grande probabilidade de se conservar direito. (QUEIRÓS, 1913, p. 103)

Suprimi a Inglaterra da face do Globo, e imediatamente vereis, com surpresa e com dor, que a superfície do Globo tem uma nacionalidade de menos. (QUEIRÓS, 1913, p. 103).

Ou seja, percebe-se uma crítica ao culto de jornais e outras fontes de informação (no caso do conto, o jornal Times) como fonte de verdade absoluta, além da vulgaridade dos posicionamentos e a incapacidade (dos leitores e mesmo dos redatores) de um raciocínio abstrato e coerente.

Assim, a escolha de um animal como crítico observador, no caso o cão, se configura como tentativa de um segundo/novo olhar para tais questões, um vivente fora da esfera do humano. Haveria algo em nós que só é reconhecido pelos animais? O pensador Jacques Derrida, em O animal que logo sou (2002), reflete como ao pensarmos no olhar do animal sobre nós, estamos questionando o estatuto do humano, numa espécie de crise:

Diante do gato que me olha nu, teria eu vergonha como um animal que não tem o sentido de sua nudez? Ou, ao contrário, vergonha como um homem que guarda o sentido da nudez? Quem sou eu então? Quem é este que eu 


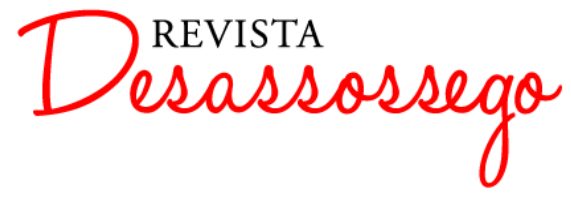

DESASSOSSEGO 19 | JUN/2018 | ISSN 2175-3180

DOI: http://dx.doi.org/10.11606/issn.2175-3180.v10i19p26-38

sou? A quem perguntar, senão ao outro? E talvez ao próprio gato? (Derrida, 2002, p. 18 - destaques do autor)

Ao longo dos anos, muitos filósofos, como Platão, pensaram a questão homem/animal pelo viés da semelhança entre ambos, numa aproximação das espécies. Ainda que possamos falar numa aproximação biológica e de uma herança genética, para Derrida, pensar a questão do humano e do não humano à margem do pensamento centrista ocidental só se torna viável pelo não apagamento das diferenças, o que assinala a identidade e subjetividade de cada ser vivente.

O filósofo cria um novo vocábulo para pensar filosoficamente o animal, que ele nomeia animot. Tal expressão seria a junção das palavras francesas animaux (animal) e mot (palavra), ou seja, o animal enquanto discussão, e ainda enquanto escritura, que se configura com sua inserção no pensamento filosófico através da criação de um conceito próprio para o tema.

Derrida afirma que "ele (o animal) tem seu ponto de vista sobre mim. O ponto de vista do outro absoluto, e nada me terá feito pensar tanto sobre essa alteridade absoluta do vizinho ou do próximo quanto os momentos em que eu me vejo visto nu sob o olhar de um gato". (op. cit., 2002, p. 28). O humano tende a julgar o outro, que não ele mesmo, e se refletimos um instante, a possibilidade de que o outro também nos observe se abre diante de nós, como ilustrado nas reflexões do cão D. José sobre o comportamento inglês e francês.

D. José demonstra, pela narrativa e pelo outro narrador, ter sido seduzido pelo comportamento e ideias consideradas como próprias da humanidade. Ainda assim, ao trazer a voz de um animal à narrativa, ao lhe dar uma forma para ser lido, ainda que sob uma perspectiva humana do pensamento animal, o conto abre um espaço interessante e necessário para a discussão do animal em nossa cultura e torna-se um convite para olharmos para este outro, que no texto, reflete a própria condição do humano.

Em realidade, é o humano que passa a ser o outro, no texto. É ele que passa a ser objeto de estranhamento, a partir do ponto de vista do cão, que vai aos poucos deslindando as mazelas da vida social inglesa, de modo aparentemente ingênuo e despretensioso. Certamente não é no Amigo da Imparcialidade, versão inglesa do Conselheiro Acácio (e ainda pior que ele), que se encontra a verdade sobre os humanos em geral; e sobre ingleses e franceses, em particular. Como os animais são desprovidos de vaidade e pretensão, são autênticos em suas atitudes, a escolha do cão como analista social não se dá por acaso. É 


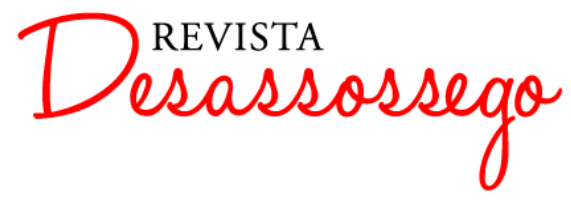

DESASSOSSEGO 19 | JUN/2018 | ISSN 2175-3180

DOI: http://dx.doi.org/10.11606/issn.2175-3180.v10i19p26-38

uma personagem assim uma boa opção para um texto irônico, que tenta atacar uma sociedade hipócrita, insensata e cega, cuja maior habilidade consiste em fazer propaganda de virtudes que não tem.

\section{Referências Bibliográficas:}

AGAMBEN, Giorgio. Homo Sacer: o poder soberano e a vida nua I. Tradução de Henrique Burigo. Belo Horizonte: Editora UFMG, 2002. 207p. - (Humanitas).

ANDRADE, Oswald. Memórias Sentimentais de João Miramar. São Paulo: Companhia das Letras, 2016.

ANDRADE, Oswald. Serafim Ponte Grande. Rio de Janeiro: Biblioteca Azul, 2006.

BÍBLIA SAGRADA. Português. Gênesis. In: Bíblia Sagrada - edição pastoral. Tradução, introduções e notas de Ivo Storniolo e Euclides Martins Balancin. São Paulo: Paulus, 1990.

DERRIDA, Jacques. O Animal que logo sou. Tradução Fábio Landa. São Paulo: Editora UNESP, 2002.

DICKENS, Charles. The Pickwick Papers. Londres: Penguin Books, 2016.

FERRY, Luc. O que é o ser bumano?: sobre os princípios fundamentais da filosofia e da biologia/ Luc Rerru, Jean-Didier Vincent; tradução de Lúcia Mathilde Endlich Orth. Petrópolis, RJ: Vozes, 2011.

FREELAND, A. O Leitor e a Verdade Oculta: Ensaios sobre Os Maias. Lisboa: Imprensa Nacional - Casa da Moeda, 1989.

FUNDAÇÃO EÇA DE QUEIRÓS. "Cronologia de Obras”. Disponível em: https://feq.pt/o-escritor/cronologia-de-obras/>. Acessado em 26/10/2017.

LESTEL, Dominique. As Origens Animais da Cultura. Instituto Piaget. Coleção Epistemologia e Sociedade. Tradução de Maria João Batalha Reis. 2002.

MINÉ, Elza. Páginas Flutuantes: Eça de Queirós e o jornalismo no século XIX. São Paulo: Ateliê Editorial, 2000. v. 1. 244p.

MINÉ, Elza. Eça de Queirós jornalista. 2. ed. Lisboa: Livros Horizonte, 1986. 126p.

QUEIRÓS, José Maria Eça de. “Antero de Quental”. In: QUEIRÓS, José Maria Eça de. Notas Contemporâneas. Porto: Lello\&Irmão, p. 339-387.

QUEIRÓS, José Maria Eça de. "A Inglaterra e a França julgadas por um inglês". In: 


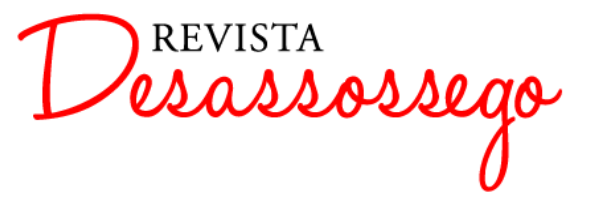

DESASSOSSEGO 19 | JUN/2018 | ISSN 2175-3180 DOI: http://dx.doi.org/10.11606/issn.2175-3180.v10i19p26-38

QUEIRÓS, José Maria Eça de. Notas Contemporâneas. Porto: Lello\& Irmão, p. 99-114.

MINÉ, Elza. "Introdução”. In: QUEIRÓS, José Maria Eça de. Textos de Imprensa IV. Edição

Críticas das obras de Eça de Queirós. Coordenação de Carlos Reis. Edição de Elza Miné e Neuma Cavalcante. Lisboa: Imprensa nacional/Casa da Moeda, 2002, p. 11-51. 